\title{
Delors white paper puts research firmly on Europe's political map
}

Paris. Europe's political leaders have given their formal endorsement to proposals that would enlarge their common research programmes, encourage the joint construction of new 'information highways' and increase incentives to persuade industry to invest in research.

At their summit meeting in Brussels last weekend, the leaders of the 12 member states of the European Union (EU) approved a white paper (policy document) on competitiveness, growth and unemployment prepared by Jacques Delors, the president of the commission. The paper is aimed at creating 15 million jobs in the EU by 2000 .

Three of its ten chapters dealt exclusively with research and development (R\&D). The EU's acknowledgement of the importance of R\&D to its plans for economic recovery was further reinforced at the summit, when the heads of government also

\section{Deadlock broken on}

\section{Framework funding}

Paris. The leaders of the European Union (EU) ended uncertainty about the next fiveyear Framework research programme last Friday by agreeing to a budget of "at least" ECU12 billion (US $\$ 13.6$ billion), and a reserve of ECU1 billion, for the period 1994-98.

The heads of government acknowledged that the research programme was an important part of its plans for economic recovery (see above). In the final communique, they declared that the implementation of "an ambitious, well-targeted research programme constitutes a significant contribution to efforts towards recovery, particularly in areas such as information technology".

The programme had been hanging in the balance earlier in the week, after the council of research ministers failed to agree on the budget of ECU13.1 billion proposed by the European Commission. and had passed the buck to the summit (see Nature 366, 499; 1993).

The commission is now confident that the council of ministers will iron out its remaining disagreement over the funding of the EU's four Joint Research Centres at an extraordinary meeting a few days before Christmas. The Framework programme is then expected to pass easily though its final reading before the European Parliament, and to come into effect some time next year.

D. B. broke the deadlock over the funding of the EU's next five-year Framework programme, by approving a budget of ECU12 billion (US\$13.6 billion, see sidebar).

In his white paper, Delors sets the EU the ambitious target of increasing spending on R\&D to three per cent of gross national product (GNP). It now spends just 2 per cent (ECU104 billion) in contrast with the United States, which spends 2.8 per cent (ECU124 billion) and Japan three per cent (ECU77 billion)

Such a large increase in spending seems improbable, given that member states have either frozen or cut science spending because of the economic downturn. Nevertheless, Delors is confident that the private sector could make up the difference. Companies fund just over half of all science spending in Europe, compared with more than three-quarters in Japan.

To this end, Delors encourages member states to provide tax and other incentives to companies to invest in research. He also wants the EU to make its rules for cofunding industrial research more flexible (see Nature 365, 775; 1993).

Delors also criticizes the lack of coordination between national research policies. His remedy would be to formalize cooperation within some form of European science agency, but it is too soon to say how this would operate. He also wants member states to take joint measures to improve technology transfer.

He recommends that national research organizations, companies and social groups need to develop a European strategy for biotechnology as a matter of urgency. $\mathrm{He}$ has also instructed the commission to consider revising legislation affecting biotechnology products.

The white paper proposes that governments encourage companies to work together on several big projects in the fields of information technology, biotechnology and environmental technology. The Euro-

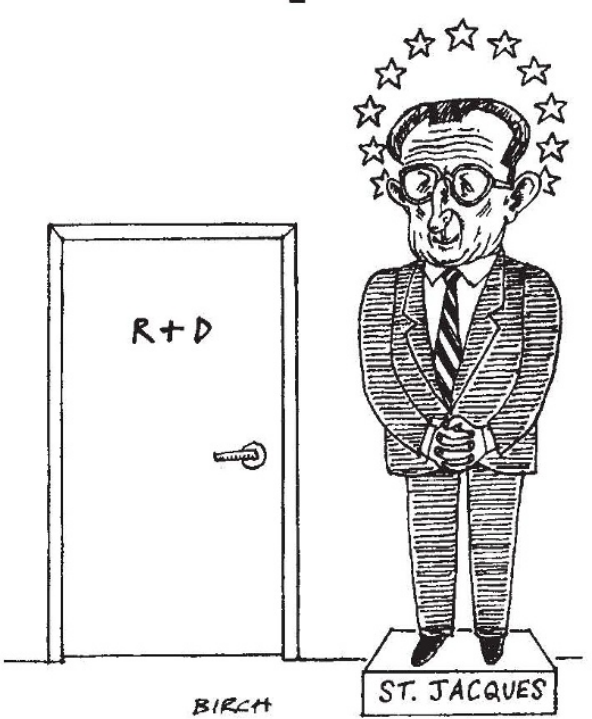

pean Round Table, which brings together 40 leading industrialists, backs the plan.

The paper suggests ECU150 billion should be spent on information technology infrastructure over the next ten years. Furthermore, it accords priority to eight projects, including building a high-speed communications network and developing databases and electronic mail, requiring ECU67 billion in 1994-98.

Delors wants the EU to set up a highlevel "Task Force on European Information Infrastructure" to plan the programme and start it by the middle of next year. Although EU has agreed to provide ECU12 billion a year for six years to create networks in transport, energy and telecommunications, it anticipates that most of the money for the electronic highway will come from the private sector.

It is too soon too say what effect the EU summit's adoption of the Delors plan will have on science and technology. Although the member states have committed themselves to implementing the white paper's recommendations, these are non-binding and will inevitably be subject to change.

Declan Butler

\section{Newspaper ducks criticism of AIDS coverage}

London. Under a 360-point heading set in blood-red type "AIDS - why we won't be silenced", Britain's Sunday Times this week (12 December) accuses Nature of "sinister intent" and of being "so tied to one particular hypothesis of Aids as to make it feel anybody who questions that theory must not only be in error, but must be silenced".

In particular, the newspaper criticizes John Maddox, editor of Nature, for his alleged refusal to publish articles "from doctors and scientists who question the HIV Maddox as the "high priest" of Nature, and the journal as the "bible of the church of science". But it also concedes that the HIV virus may be involved in the onset of AIDS in some unspecified way.

The Sunday Times reprints the leading article from last week's Nature (366, 493$494 ; 1993$ ), and purports to respond to the questions raised. But the points made theory of Aids". The newspaper describes 